\title{
As mãos de António Pedro
}

\section{Pedro Eiras}

ILCML / Universidade do Porto

Resumo: Este ensaio analisa a representação das mãos na obra poética e pictórica de António Pedro, especialmente entre 1931 e 1942. De uma representação hierática às experiências dimensionista e surrealista, a mão torna-se um dos mais importantes símbolos do poeta e do artista.

Palavras-chave: António Pedro, mãos, poesia, imagem, intermedialidade

\begin{abstract}
This essay analyses the representation of hands in the poetic and pictographic work of António Pedro, namely between 1931 and 1942. From a hieratic representation to the dimensionist and surrealistic experiences, the hand becomes one of the most important symbols of the poet and the artist.
\end{abstract}

Keywords: António Pedro, hands, poetry, image, intermediality

São muitas as mãos de António Pedro, muitos os ofícios: poeta, ficcionista, dramaturgo, jornalista, ensaísta, editor, encenador, pintor, escultor, galerista - pelo menos. Seria preciso compreender como todas estas linguagens dialogam, sem perda das suas especificidades, mas também sem o isolamento que uma teoria essencialista das artes secularmente propõe; compreender, em suma, de que modos a mão do pintor se encontra 
com a do poeta, a do encenador com a do ficcionista, deslocando de cada vez a divisão dos géneros e criando formas que resistem a apressadas catalogações.

Ora, se invoco as mãos de António Pedro, é também no sentido de um objecto inquirido: mãos desenhadas em livros, pintadas em telas, ditas e escritas em poemas e ficções, com tal constância que a mão em António Pedro se torna "ritual" (Azevedo 1979: 39), obsidiante imagem de marca, ubíqua mas nunca menos misteriosa, como se a sua insistência apenas viesse aprofundar o enigma da sua significação. Precisamente: o que são, para que servem, que significam as mãos tantas vezes apresentadas neste autor - e será que elas devem sequer ter algum significado, ou significados?

A mão pode ser uma coisa, um objecto, simples matéria inerte; mas também, ao invés, metonímia de um sujeito, símbolo de um desejo ou de uma acção; e ainda: acção controladora ou libertadora, tomada de posse ou desprendimento e abandono. Talvez a mão possa ser, como avança a antropologia, um significante livre: o seu significado depende por inteiro de um contexto, uma circunstância que lhe confere legibilidade. Decerto sabemos o que uma mão é; mas o que ela significa num poema ou numa tela dependerá de uma linguagem que lhe confere sentido - ou que a torna resistente a todos os sentidos, densa obscuridade.

Quase nada direi do dramaturgo, do encenador, do pensador do teatro - mas vale a pena, para começar a pensar as mãos em António Pedro, lembrar este apontamento, recolhido por Fernando Matos Oliveira em Escritos sobre Teatro:

"Don't show your feelings", ensina-se, de pequenos, aos meninos ingleses bem educados. Não mostre os seus sentimentos e as suas emoções, contenha-se... e talvez por isso, talvez porque os sentimentos e as emoções não se exibem permanentemente na rua, no palco, quando é preciso mostrá-los e comunicar com o público, os ingleses são tão bons actores. 0 gesto, normalmente não existente, ganha em sobriedade uma expressão enorme.

Nós, os latinos, gesticulamos demais. Enchemos de vazio, pela superabundância, o significado dos nossos gestos. (...) É indispensável criar-se em palco uma economia do gesto. (António Pedro 2001: 281)

Evidentemente, não se gesticula apenas com as mãos: existem gestos próprios de 
cada parte do corpo, e uma comunicação específica de cada órgão. Mas, para pensar a significação das mãos em António Pedro, pode-se partir desta reflexão sobre a "economia do gesto", a "expressão enorme", consciente, que as mãos ganham neste pensamento sobre o teatro - ou sobre a arte em geral. Uma estratégia da significação das mãos, estratégica, motivada e resistente, eis o que procuro no ofício múltiplo de António Pedro.

De seguida, a mão surgirá muitas vezes isolada do corpo: mão sem braço, não necessariamente decepada, nunca sangrenta, mas amiúde mais expressiva no seu gesto precisamente por não depender da totalidade de um organismo, isto é, de uma gramática já conhecida. Para interrogar a importância desse isolamento da mão, importa recordar alguns versos de Mário de Sá-Carneiro, não por acaso uma das influências mais evidentes na poesia do jovem António Pedro. Cito um excerto do poema "16", decerto o mais escandaloso de todos os textos de Orpheu 1:

As mesas do Café endoideceram feitas Ar...

Caiu-me agora um braço... Olha lá vai ele a valsar,

Vestido de casaca, nos salões do Vice-Rei...

(Subo por mim acima como por uma escada de corda,

E a minha Ânsia é um trapézio escangalhado...) (Sá-Carneiro 2001: 75)

É certo que Sá-Carneiro não descreve a existência autónoma de uma mão, mas a queda de um braço; e o contexto destes versos explora um universo burlesco, présurrealista, histericamente absurdo, tanto mais que os leitores de 1915 não compreenderam o que havia de doloroso nesta imagem de um sujeito-apenas-parte-de-simesmo, bocado caído, fazendo salamaleques ao poder. Mas toda a tradição da fragmentação do corpo no modernismo, que aqui alcança a mais escandalizada das recepções, é fundamental para compreender a experimentação de António Pedro.

$\mathrm{Na}$ verdade, a primeira mão que me interessa estudar será particularmente hierática. Trata-se de um desenho que António Pedro inclui no fim do seu sexto livro de poemas, Máquina de Vidro. Canções, publicado em 1931: 


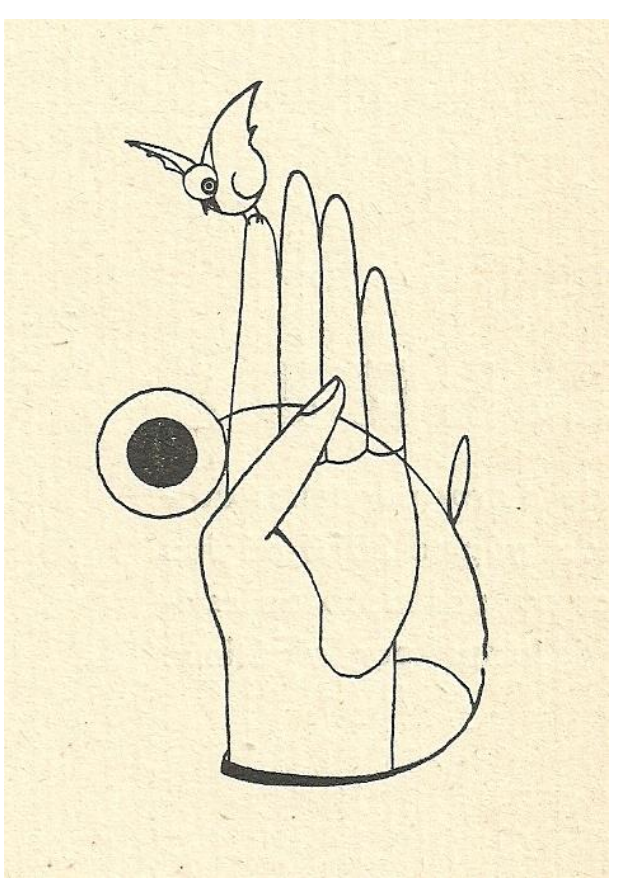

Este desenho surge no fim do livro de poemas, não entre os poemas: pelo menos por enquanto, nada indica que o desenho aspire a ser compreendido como um poema. Paratextual, ele pertence ao livro e excede o livro, como se fosse uma assinatura do autor, impressão digital ou, melhor, manual. Na verdade, a função deste desenho de uma mão é, e decerto deve permanecer, obscura: despedida? Ou, quando o mesmo desenho reaparece, no ano seguinte, no início do livro $A$ Cidade, saudação? Nem sabemos se a mão se dirige ao leitor, ou aspira ao pássaro, ou sustenta a flor. Sabemos, porém, que é uma mão solene, vertical, rectilínea. Em comparação com o corpo caótico do poema de Sá-Carneiro, esta mão recupera uma ordem clássica; e se o braço que valsa nos salões do Vice-Rei é ridículo e doloroso, esta mão é solene e capaz, mesmo na ausência do restante corpo. Dito de outro modo, esta mão é isolada do organismo, mas nada lhe falta: embora seja uma parte, ela é também inteira, suficiente.

Importa ainda perguntar: o que faz este desenho num livro de poesia, ou melhor: o que faz este desenho aos próprios poemas? De que modo a imagem gráfica altera a interpretação das imagens poéticas, isto é, realizadas com palavras e não com linhas? Mas 
também, inversamente: o que fazem os poemas, as imagens poéticas, a este desenho, imagem gráfica, e o que se deve ver nesta página depois de ler as páginas anteriores?

Citarei apenas alguns versos da "Canção vigésima-segunda", que evocam indirectamente a mão:

Fiz do meu corpo um bailado, dos meus gestos, gestos fáceis, e das palavras, fiz gráceis teclas vivas dum teclado. (Pedro 1931: 22)

A mão é evocada pelo menos duas vezes: nos gestos e no teclado; talvez também no bailado. E se as palavras são teclas vivas, então tornam-se materiais, alcançáveis pela mão: a matéria verbal do poema é dita uma matéria táctil. 0 sujeito, por seu turno, mostra-se capaz, demiúrgico, moldador de si mesmo: contra a incapacidade do corpo em Sá-Carneiro, António Pedro defende aqui um corpo poderoso ao ponto de se auto-inventar. Mas se o corpo dança, se o corpo se define como o próprio bailado, que dança pode ser a da mão ainda grave, desenhada no fim de Máquina de Vidro? Talvez o movimento evocado pelo poema não encontre ainda paralelo na mão final, onde apenas o pássaro parece querer lançar-se no vazio.

Mesmo se pode haver uma tensão entre a proposta do poema e a proposta do desenho, um diálogo inicia-se. Terá um importante desenvolvimento alguns anos mais tarde, com o entusiasmo de António Pedro por dois movimentos de vanguarda: o planismo e o dimensionismo.

Como se sabe, o poeta húngaro Charles Sirato escreve em 1935 o seu "Manifeste planiste", propondo a exploração da mancha gráfica do poema na página. Conforme defende, se a literatura tradicional é a expressão na linha, o planismo propõe a expressão no plano, explorando as potencialidades da disposição dos elementos gráficos numa dada superfície; trata-se portanto de investigar conjuntamente os recursos da escrita, do desenho, da montagem, cruzando artes e géneros. Sirato integra-se, assim, numa tradição que inclui a experimentação sobre a mancha gráfica na poesia barroca, Un Coup de Dés 
Jamais n'Abolira le Hasard de Stéphane Mallarmé, os caligrammes de Guillaume Apollinaire, ou "Manucure" de Mário de Sá-Carneiro. Por outro lado, desenvolve uma teoria do diálogo entre escrita e imagem cerca de duas décadas antes da poesia visual, concreta e experimental brasileira e portuguesa.

Ainda em 1935, Charles Sirato desenvolve a proposta do planismo escrevendo o "Manifeste dimensioniste", um texto assinado por vinte e seis artistas, incluindo Alexandre Calder, Francis Picabia, Joan Miró, Marcel Duchamp, Robert e Sonia Delaunay, Wassily Kandinsky - e António Pedro, nesse instante a viver em Paris, em contacto directo com a vanguarda. No ano seguinte, Pedro publicará, no número 1 da revista Cartaz, um "Manifesto-resumo do dimensionismo" antecedido de uma "Nota circular acerca de mimmesmo", assumindo o seu entusiasmo pela proposta daquele movimento estético e teórico.

Assim, segundo o "Manifesto-resumo do dimensionismo" de António Pedro,

a tendência dimensionista obrigou:

I... A literatura a sair da linha e a passar ao plano. (...)

II... A pintura a fugir ao plano e a ocupar o espaço. (...)

III... A escultura a abandonar o espaço fechado imóvel e morto, isto é, o espaço a três dimensões de Euclides, para sujeitar à expressão artística o espaço a quatro dimensões de Minkovsky. (1998: 9899)

Em suma, o limite de cada arte é transgredido pela inclusão de uma dimensão suplementar, deslocando as identidades dos géneros; não se trata apenas de reunir várias artes numa Gesamtkunstwerk wagneriana, mas de recusar radicalmente o próprio condicionamento dessas artes em meios ou formas estritos, a arrumação das artes num sistema rígido: "todos os antigos limites e fronteiras das artes desaparecem", diz o "Manifesto-resumo" (ibidem: 98), ou, como esclarece a "Nota circular acerca de mimmesmo", "Os estados poéticos que a tradição convencionou serem transmitidos em verso (forma a uma dimensão) podem também servir-se como meio de devolução sensível da forma a duas dimensões (plano) e a três dimensões (volume)" (1998: 97). Momento importante da teorização de António Pedro: os limites do poético só convencionalmente são o verso - mas pode haver poesia a duas ou três dimensões. 
Nesse sentido, e porque “A poesia precisa cada vez menos de palavras” (Pedro 1998: 97), o poético pode consistir numa pintura ou numa escultura: a poesia manifesta-se no espaço. Assim, é também um poema o Aparelho Metafísico de Meditação, criado por António Pedro em 1935: um prisma triangular de madeira, sobre o qual podem girar dois discos de plástico, com pequenos sintagmas verbais: "o homem”, “de deus", "fez", "querido"; conforme os discos giram, constroem também enunciados filosóficos, teológicos, poéticos. Como escreve Maria de Fátima Lambert, "A inovação da obra circunscreve-se também no que era a intencionalidade relacional ao público, solicitando-lhe uma acção directa sobre a obra em si, outorgando-lhe movimento, acção no espaço, sob efeito da condição do tempo individuado. Cada rotação do dispositivo iria assinalar uma das três frases sugestionadas. 0 acaso primava" (2016: 7): escrita, imagem, forma, espaço e tempo, autoria e colaboração do público, controlo e acaso encontram-se assim, num dispositivo (inter)dimensionista, de impossível catalogação.

Mas regressemos ao tratamento das mãos. Do livro Solilóquio Mostrado, também de 1935, cito o "Poema duma ansiosa exaltação":

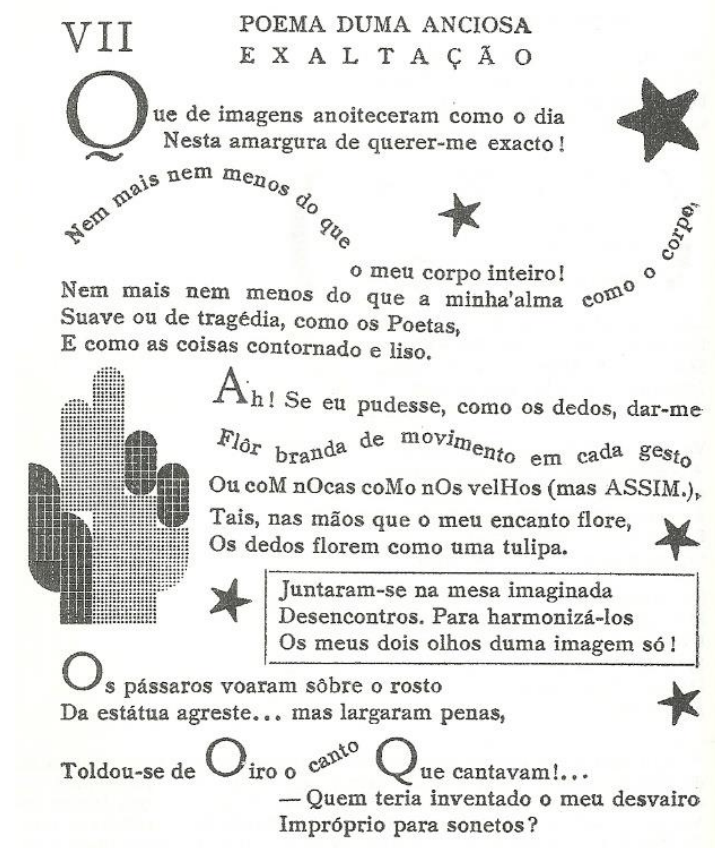

(Pedro 1998: 34) 
O título indica que estamos perante um poema - e o dimensionismo já postulou que o poético não reconhece as fronteiras que lhe são tradicionalmente atribuídas. Poema, desenho, composição, montagem são designações conciliáveis, não concorrentes. De resto, o poema parece aceitar uma disposição livre, imprevisível, caótica - enquanto o discurso verbal manifesta exuberantemente os desejos de exactidão, inteireza, movimento, florescimento, harmonia. Instabilidade, pois, da vontade, em simultâneo com a inventiva instabilidade da forma, cruzando a dimensão da escrita com a dimensão do desenho. Ora, também aqui a mão reaparece - como palavra: “dedos", "mãos", e como imagem: na verdade, novamente uma mão vertical, rectilínea, estilizada em formas geométricas. É certo que a mão permanece ainda solene, algo rígida, e teórica, sistematizada como conjunto de formas regulares. Mas o seu surgimento dentro dum "poema", como parte dele, coloca novas questões; por exemplo: esta mão é um verso? uma estrofe? um aposto à palavra "mãos"? Ou é a palavra "mãos" que constitui um aposto à imagem da mão? Qual é o limite da imagem e qual o limite das palavras?

Questões que se podem repetir perante um poema de Quinze Poèmes au Hasard, ainda de 1935:

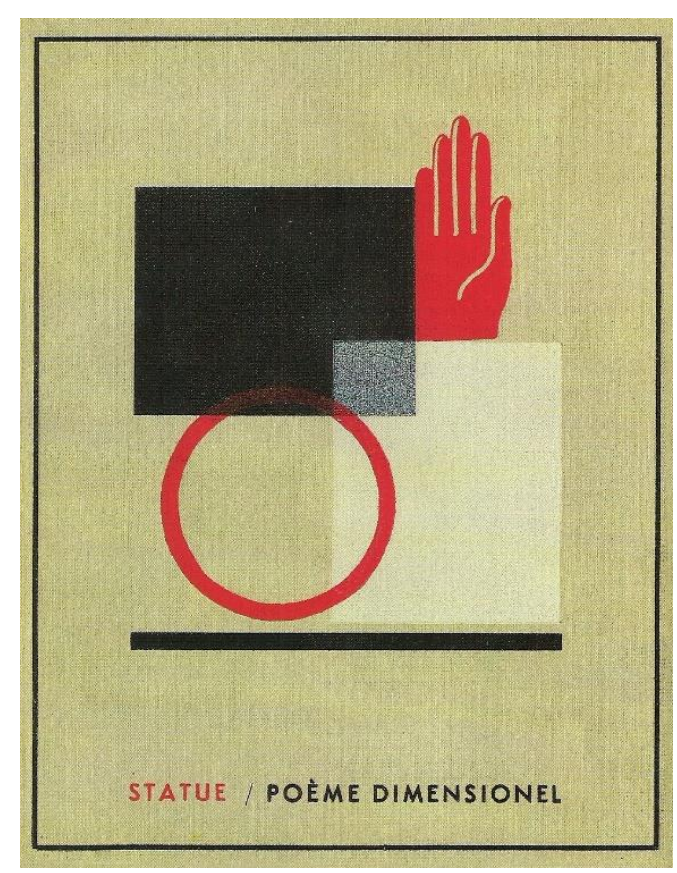

(Pedro 1998: 42) 
Socorro-me novamente do título: "Statue / poème dimensionel". Decerto o título é "Statue", estátua, e "poème dimensionel” um subtítulo ou uma legenda genológica. Novamente, a palavra "poème" é fundamental para designar esta obra híbrida, plural, interdimensional; e tanto mais que, excluindo o próprio título, não há palavras neste poema: apenas formas num plano, espaço, simultaneidade. Libertação das regras dos géneros e das classificações, mais uma vez. Quanto à mão representada, porém, permanece estilizada, sucinta nas suas linhas minimais, paralelas, ainda rígidas: tem algo de estátua, como sugere o título, e se há neste poema um jogo de oposição entre formas geométricas e uma forma orgânica, certo é que a própria mão preserva um minimalismo esquemático, um controlo de que António Pedro muito em breve se afastará.

De facto, a lição do dimensionismo, uma vez interiorizada, é esquecida durante os anos seguintes - ou transmudada noutras experiências. Como escreve Fernando de Azevedo num ensaio sobre o ensaísmo de António Pedro,

Ainda que o movimento não tenha tido sequência como tal, penso que em António Pedro o dimensionismo perdurou, aprogramático embora, mas subjacente a toda a sua obra, mesmo naquela que não é só a pintura ou a poesia: o teatro. (...) Mas foi pelo menos através da criação dimensionista que António Pedro desprendeu uma força subterrânea que viria a exaltar-se tanto na sua poesia como na sua pintura e nesta última seria o motor invisível que o iria aproximar do surrealismo e, depois, decidir como surrealista. (1979: 39)

Seria interessante repensar o teatro de António Pedro como uma experiência de dimensionismo, deslocação sistemática das artes para uma dimensão suplementar; mas enveredo antes pela experiência surrealista, pela aceitação de uma desordem que o rigor geométrico do dimensionismo ainda impede. Só nesse momento a representação da mão perderá o hieratismo - embora não a sua força inquietante.

Do livro de poemas Casa de Campo, publicado em 1938, cito excertos da secção intitulada "Viagem". Mais exactamente, os poemas, ou desenhos, ou partes de uma sequência, números 1, 3 e 5: 
Pedro Eiras
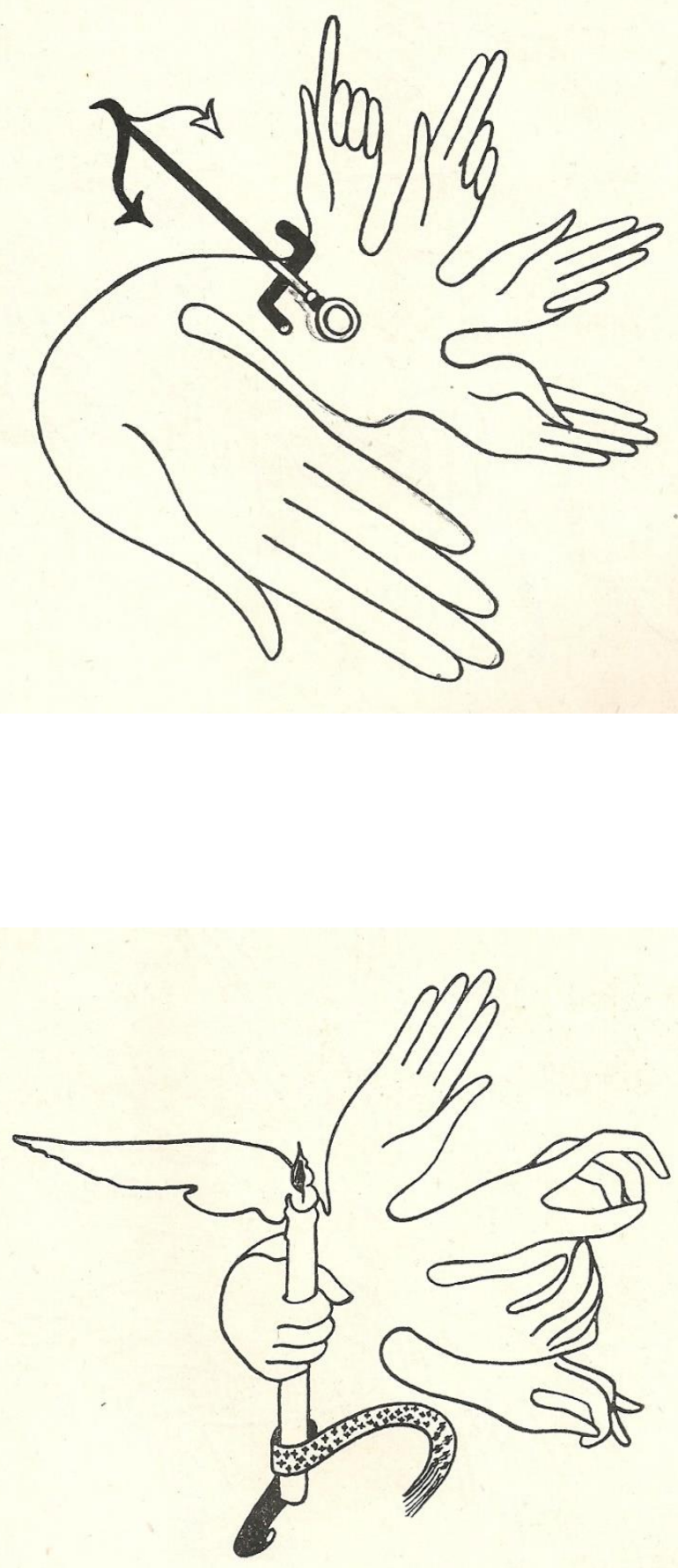


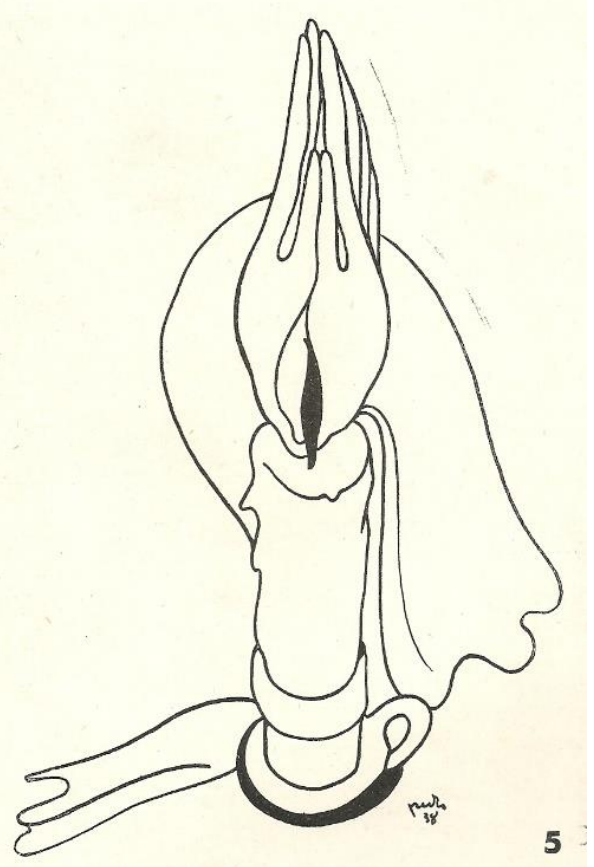

(Pedro 1938)

É difícil descrever ou parafrasear estas páginas: na primeira, cinco mãos, ou uma mão multiplicada, ou uma mão cujos dedos são outras mãos, contam de um a cinco - gesto minimal e obscuro (contam o quê?); "sobre elas, uma âncora-anzol prende a liberdade que estas prometiam", comenta Fernando Matos de Oliveira (1998: 43). 0 poema, ou desenho, ou objecto dimensionista, torna-se assim político. Na terceira página, as mãos (outras, as mesmas?) sustêm uma vela, referência religiosa. Na quinta, elas próprias, em gesto de prece, são a chama da vela - evocando talvez La Cathédrale de Rodin. As mãos são sujeito da acção e objecto da acção, transmutação - corpo feito bailado, como António Pedro escrevia em Máquina de Vidro. Ou talvez mãos-pássaros (na terceira página as mãos prolongam-se numa asa), mãos-voo.

A lição dimensionista foi evidentemente aprendida, mas também decerto ultrapassada. Como escreve ainda Fernando Matos Oliveira, "A atracção" de António Pedro pelo dimensionismo "tinha que ver com as virtualidades plásticas do projecto, a que era obviamente sensível. 0 afastamento estava no que esta poesia acabaria por pedir de abstracção" (1998: XXVIII). A plasticidade permanece, de facto, em Casa de Campo, e assim 
também o desafio a uma teoria dos géneros, incluindo desenhos entre poemas, ou reconhecendo o desenho como poema através de uma dimensão planista, dimensionista, suplementar. Mas "Viagem" desfaz a abstracção geometrizante do dimensionismo: as mãos perdem finalmente a rigidez, para ganharem movimento, metamorfose.

E também fragilidade: contra a mão firmemente erguida dos poemas ou desenhos anteriores, estas mãos realizam gestos que desafiam a identidade delas, tornando-as asas ou velas. Mais ainda, estas mãos anunciam a filiação de António Pedro no surrealismo, inauguram uma apresentação do desejo. Côncavas, elas permitem receber um corpo apenas prometido, como veremos. Aceitando a metamorfose, a preensão, o contornar dos objectos, as mãos entram em relação com o mundo. Como escreve Jean Brun em A Mão e o Espírito,

Se a mão foi privilegiada por todos os gnosticismos do tempo que esperaram dela a revelação do passado e a construção do futuro, é porque ela é aquilo por que o homem é levado na direcção do que lhe falta; para tal, a mão foi considerada como o que podia iniciar naquilo que já não era e no que ainda não era. Mas a ausência que a mão quer sondar no extremo do braço estendido não é somente a ausência que um ter possa colmatar, é sobretudo uma ausência de ser, pois, com a sua mão aberta, o próprio homem abre-se ao que ele não é. O erro é acreditar que a preensão possa colmatar esse intervalo e que o conhecimento do arcaico seja capaz de nos iniciar no conhecimento do originário. (1990: 121)

Que a mão nunca colmate o intervalo, que nunca alcance o objecto, mesmo tocandoo, nada deve ter de trágico; pelo contrário, é essa distância intransponível em relação ao mundo que cria o mundo e o desejo. Essa condição, de resto, deve ser inventada: que "o próprio homem [se abra] ao que ele não é”, eis a conquista das mãos de António Pedro, já não geométricas, mas doravante capazes de arriscarem a sua forma, a forma daquilo que já são, ansiando por aquilo que aspiram a ser.

Em suma, doravante as mãos flectidas são vontade, demanda, angústia, encontro e devir, multiplicação de gestos discordantes e em tensão contínua. Observarei uma única tela de António Pedro, A Ilha do Cão, de 1941: 


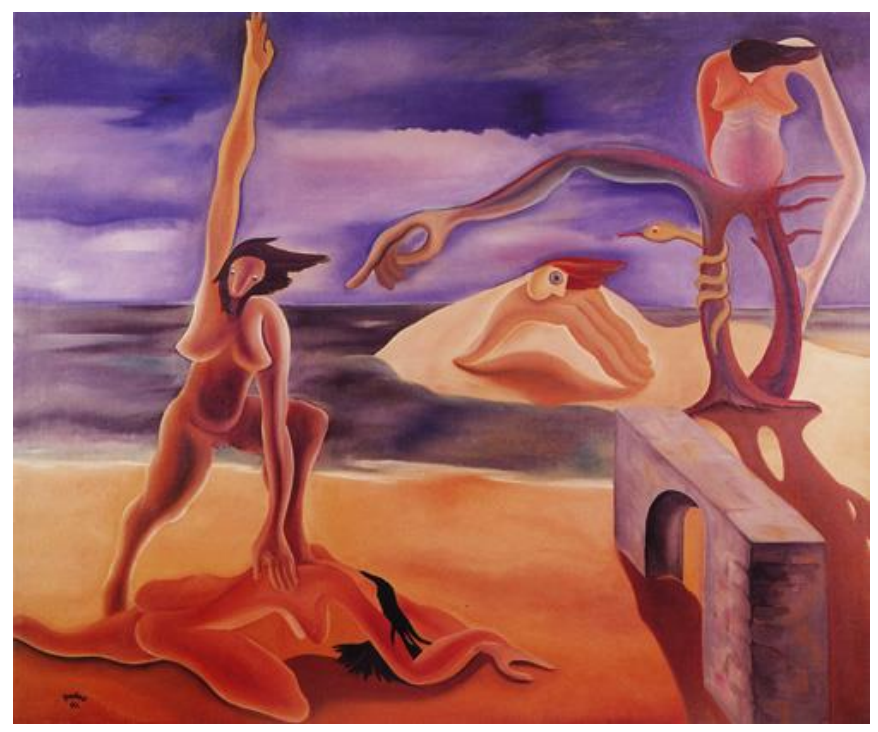

Profusão de gestos, realizados por seis mãos, e resistentes a qualquer interpretação, ou mesmo paráfrase. É difícil dizer quem são estas personagens, a quem pertencem as mãos, o que desejam: bater, apontar, subjugar, medir? Compreendemos apenas que elas são movidas por intenções, dirigem-se a objectos, mas o sentido dos gestos deve permanecer obscuro. Segundo Giuseppe Ungaretti, há aqui uma

procura de estilo, a do movimento das figuras ora pacato, ora de louco tripúdio, ora simplesmente fatal, ora curvo, ora horizontal, ora vertical, ora insinuante. Não se pode omitir uma busca de perspectiva neste quadro pois ela está ligada a uma procura de movimento espacial (...). 0 movimento de saída da perspectiva, que se torna brusco na linha do horizonte, é intensificado e encarcerado para a vida na grade formada pelos objectos que o quadriculam: arco, figuras, etc. (1979: 13)

Confronto, pois, do movimento e do encarceramento: as mãos desta tela surrealista são livres mas presas, presas mas livres.

Pouco ou nada podemos saber da identidade das três mulheres; constatamos apenas que elas não estabelecem um contacto visual, uma interlocução. São obscuros os gestos da mulher erecta que subjuga (?) a mulher deitada na praia. Não se sabe a quem pertence a mão que aponta, nem porquê. Só com grande liberdade hermenêutica se pode considerar a serpente uma referência à tentação bíblica, transmudando as três mulheres em Evas. 
Quanto à mão arqueada, e encimada por uma cabeça, na península em segundo plano, podemos apenas compará-la com as mãos voadoras de Casa de Campo; se estas eram pássaros, a mão de Ilha do Cão é um animal terreno, preso à paisagem. Contra as mãos geométricas no dimensionismo, trata-se agora de uma mão flexível, talvez desejante; mas por que não parece, então, jubilosa?

Sobre telas de António Pedro como esta, José-Augusto França escreve: "era uma pintura nunca vista que se formara em outras raízes culturais, com uma fundamentação poética de recusado lirismo" (2007: 26). Existe, assim, fundamentação poética, mas não fundamentação lírica; o lirismo deve ser activamente recusado, numa vigilância incessante. Regresso à escrita, a uma escrita poética e não lírica, a de Apenas uma Narrativa (1942), livro ímpar no século XX português, invenção de um surrealismo que conjuga as tradições populares do Alto Minho com uma linguagem onírica, hipnótica, perturbadora. Neste livro, escreveu Jorge de Sena, “a imaginação, tantas vezes abstraccionante, do surrealismo adquire (...) um peso de regionalismo, de truculência campestre, de visão poética de uma realidade que transborda de símbolos verbais ou plásticos" (1984: 132); e Eduardo Lourenço:

Apenas uma Narrativa não desmente [a] obsessão por uma matriz tenebrosa e obscena e natural do mundo mas retira-lhe a função agressiva para a converter na mais fulgurante e bela festa que a pura imaginação investida pelas metáforas orgânicas e eróticas em estado de permanente invenção sem uma quebra se deu na nossa língua. Foi um milagre sem repetição como deve ser um autêntico milagre. (1979: 31)

Ruralidade e natureza são transfiguradas pela simbologia e pela imaginação: o muito próximo é também assustadoramente distante, heimlich é unheimlich, mas apenas porque no sentido contrário - o estranho começou por ser familiar. Basta ler o primeiro capítulo, incipit narrativo que é também uma glosa dos mitos da criação do mundo - no qual, entretanto, as mãos regressam, inquietantes. 0 capítulo começa, como todos, com um desenho: 


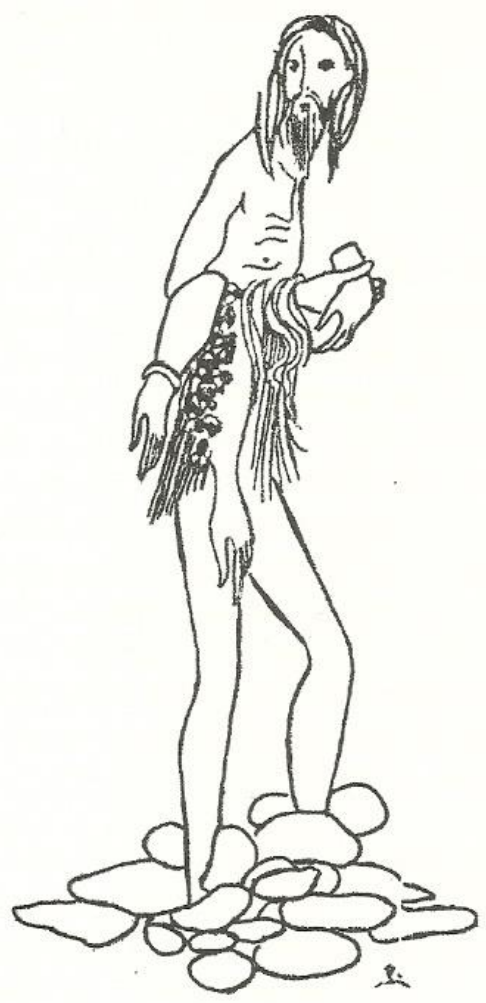

"O plantador chamava-se Adão, como é fácil de calcular."

A legenda, retirada do texto que se seguirá, só pode ser obscura para o leitor - e, de facto, toda a obscuridade de Apenas uma Narrativa é indelével: transforma-se, mas nunca se desfaz num simples esclarecimento. "O plantador chamava-se Adão, como é fácil de calcular", lê-se; é portanto o primeiro homem, este que leva olhos, cabelos, mãos: com a sua própria mão transporta mãos decepadas, a mão activa carrega mãos passivas, começa assim a luta entre as mãos e de maneira nenhuma pode advir a catedral de Rodin.

Lemos então o primeiro capítulo de Apenas uma Narrativa:

Acompanhando o leito do rio há pequenos plainos aráveis que terminam em degraus, até ao mais baixo onde se estende a planície. 0 plantador andava ali, pelo campo, enterrado até acima dos joelhos, na terra que é | ubérrima e preta. Era bonito vê-lo andar nu, o rosado do corpo a contrastar com a cor dos torrões remexidos, lançando ao longo das leivas aqueles bocados de mulher que levava num braçado. Havia braços de rainhas de mãos pendentes, brancas e com anéis, rosários de olhos como 
bolindros variegados com ternuras incalculáveis e molhadas e também com ódios e estupidez, mitras e cogumelos, como anémonas que se tinham nascido e morrido era por acaso, ao sabor do vaivém do sangue, na pele sei lá de quem. Também havia pernas e bocas, ossinhos brancos e dentes e também havia cabelos no que ele levava de braçado. Via-se que era um hábito seu aquela espécie de sementeira e, se na verdade o não era, assim parecia, enquadrada no ambiente bucólico do entardecer que, naquela parte do Minho, tem um encanto de paraíso.

(...)

O plantador chamava-se Adão, como é fácil de calcular. Não é, no entanto, verdade que fosse o primeiro homem. Antes e depois dele já havia este sabor a vazio que enche o mundo duma inquietação sem remédio. (1942: 17-20)

Não é o primeiro homem, diz o texto; nem é certo que olhos, cabelos e mãos pertençam a Evas - mas ao mesmo tempo qualquer plantador do Minho é, sim, outra vez o primeiro homem sobre uma paisagem imutável, na sementeira do seu desejo. Homem e paisagem estranhas, claro, na melhor tradição surrealista, evocando "os cenários e as personagens da pintura de Magritte, de Chirico, Delvaux ou Dalí", como escreve Fernando Pinto do Amaral (2016: 15); mas também homem e paisagem reconhecíveis, imediatos, tangíveis: lavradores, o Minho, o ciclo da morte e da germinação. 0 surreal é o real.

Seria preciso reler este capítulo à luz de tudo o que ele anuncia: todas as fragmentações dos corpos, a voracidade do querer, os rituais agrestes de personagens estagnadas, tudo o que Apenas uma Narrativa descreve entre o horror, o fascínio e uma comoção contida. As muitas violências que os corpos das personagens sofrerão nos restantes nove capítulos, num sofrimento aliás não isento de volúpia erótica, são prenunciados por esta imagem de abertura: a mão de um homem que leva uma mão de mulher, uma mão viva que leva uma mão morta, mas para a plantar, ressuscitar, num eterno retorno do desejo. Seja como for, essa demanda erótica é desesperada, porque "Antes e depois [deste plantador] já havia este sabor a vazio que enche o mundo duma inquietação sem remédio".

Mas se a mão se abre a tudo aquilo que ela não é, como não seria infinita tal inquietação? 
Nota

${ }^{1}$ Este artigo foi desenvolvido no âmbito do Programa Estratégico Integrado UID/ELT/00500/2013 e POCI-010145-FEDER-007339

\section{Bibliografia}

Amaral, Fernando Pinto do (2016), “António Pedro. Uma inquietação sem remédio”, in Jornal de Letras, 31 de Agosto: 14-15.

Azevedo, Fernando de (1979), “O ensaísta” in AA.VV., António Pedro. 1909-1966, Lisboa, Fundação Calouste Gulbenkian: 38-40.

Brun, Jean (1990), A Mão e o Espírito, trad. Mário Rui Almeida Matos, Lisboa, Edições 70 [1986].

França, José-Augusto (2007), O Essencial sobre António Pedro, Lisboa, INCM.

Lambert, Maria de Fátima (2016), "Manifesto dimensionista", in Suplemento de As Artes entre as Letras, nํ 175-176, 27 de Julho: 6-7.

Lourenço, Eduardo (1979), “O poeta e o romancista (ou a monstruosa visão de António Pedro)”, in AA.VV., António Pedro. 1909-1966, Lisboa, Fundação Calouste Gulbenkian, 1979: 29-31.

Oliveira, Fernando Matos (1998), “Introdução" e notas a António Pedro, Antologia Poética, Braga / Coimbra, Angelus Novus.

Pedro, António (1931), Máquina de Vidro. Canções, Lisboa. 
Pedro Eiras

-- (1932), A Cidade, Lisboa.

-- (1938), Casa de Campo, Lisboa, Edição do Autor.

-- (1998), Antologia Poética, ed. Fernando Matos Oliveira, Braga / Coimbra, Angelus Novus.

-- (2001), Escritos sobre Teatro, ed. Fernando Matos Oliveira, Porto, Angelus Novus \& Cotovia / Teatro Nacional de São João.

-- (2007), Apenas uma Narrativa, 3ª ed., Famalicão, Quasi [1942].

Sá-Carneiro, Mário de (2001), Poemas Completos, ed. Fernando Cabral Martins, Lisboa, Assírio \& Alvim.

Sena, Jorge de (1984), “António Pedro”, in Líricas Portuguesas, 3ª ed., vol. I, Lisboa, Edições 70: 132-133 [1958].

Ungaretti, Giuseppe (1979), “António Pedro”; ed. ut.: in AA.VV., António Pedro. 1909-1966, Lisboa, Fundação Calouste Gulbenkian: 10-14 [1942].

Pedro Eiras é Professor de Literatura Portuguesa na Universidade do Porto, Investigador do Instituto de Literatura Comparada Margarida Losa, e Membro da Rede Internacional de Pesquisa LyraCompoetics. Desde 2005, publicou diversos livros de ensaios sobre literatura portuguesa dos séculos XX e XXI, estudos interartísticos, questões de ética. Entre os mais recentes: Constelações 2 - Estudos Comparatistas (2016), Platão no Rolls-Royce - Ensaio sobre literatura e técnica (2014), e Os Ícones de Andrei - Quatro Diálogos com Tarkovsky (2012). Presentemente, desenvolve pesquisas sobre a representação e o imaginário do fim do mundo.

N. 36 - 06/ 2017 | 251-268 - ISSN 2183-2242 | http:/dx.doi.org/10.21747/21832242/litcomp36a14 